\title{
Anthelmintic efficacy of oxibendazole against gastrointestinal nematodes in swine
}

\author{
Eficácia anti-helmíntica do oxibendazol contra nematódeos gastrointestinais \\ de suínos
}

Rafael Paranhos de Mendonça'; Daniela Oliveira Carneiro²; Eliane Marucci Baccin²; Márcia Richena Pirágine²; Sara Menegatti Zoca², Luis Augusto Ferreira Rossa²; Guilherme Cecílio Lima'; Francismar Barbosa de Oliveira²; Istanlei Soares Costa²; Gabriel Nunes de Oliveira'; Sabrina Nathália Louzada Nogueira²;

Thaís Rabelo dos Santos-Doni ${ }^{3^{*}}$ (1)

'Universidade de Franca - UNIFRAN, Franca, SP, Brasil

${ }^{2}$ Médico Veterinário Autônomo, Franca, SP, Brasil

3Universidade Federal dos Vales do Jequitinhonha e Mucuri- UFVJM, Unaí, MG, Brasil

How to cite: Mendonça RP, Carneiro DO, Baccin EM, Pirágine MR, Zoca SM, Rossa LAF, et al. Anthelmintic efficacy of oxibendazole against gastrointestinal nematodes in swine. Braz J Vet Parasito/ 2022; 31(1): e018321. https://doi.org/10.1590/S1984-29612022009

\begin{abstract}
In swine production, parasites, especially gastrointestinal helminths, generate considerable economic losses. Therefore, effective control measures, such as the use of the correct anthelmintics, are of paramount importance for maintaining profitability. The aim of the present study was to evaluate the efficacy of the anthelmintic oxibendazole, administered orally, in pigs (non-industrial) naturally infected with gastrointestinal nematodes. To that end, we selected 18 pigs naturally parasitized by gastrointestinal nematodes, as determined by examination of fecal samples (eggs per gram (EPG > 500) of feces), and divided them into two groups: treated (with a 10-day course of oxibendazole) and control (untreated). After the treatment period, the animals were euthanized. During necropsy, the helminths in the gastrointestinal tract were identified and quantified. The species identified were, in order of occurrence, Ascaris suum, Trichuris suis, Oesophagostomum dentatum, and Hyostrongylus rubidus. In Brazilian swine herds, traditional (non-industrial) production systems can favor the transmission of helminths. We found that treatment with oxibendazole was $100 \%$ effective against $A$. suum and $H$. rubidus, whereas it was 99.65\% effective against $O$. dentatum and $99.20 \%$ effective against $T$. suis, significantly reducing helminth counts $(\mathrm{P}<0.01 \mathrm{for}$ all). We conclude that oxibendazole is effective in controlling the main helminths in swine.
\end{abstract}

Keywords: Anthelmintic, oxibendazole, nematodes, swine.

\begin{abstract}
Resumo
A presença de parasitoses na suinocultura gera prejuízos econômicos relevantes. Dentre elas, destacam-se as helmintoses gastrintestinais. Sendo assim, medidas de controle efetivas, tais como o uso de anti-helmínticos corretos, são importantes para a lucratividade na criação de suínos. O presente estudo teve como objetivo avaliar a eficácia do oxibendazol, administrado pela via oral, em suínos (não industrial) naturalmente infectados por nematódeos gastrintestinais, na região de Franca/SP. Para isso, foram selecionados, por meio de exames coproparasitológicos (ovos por grama (OPG > 500) de fezes), 18 suínos naturalmente parasitados por nematódeos gastrintestinais, que foram divididos em dois grupos experimentais: grupo tratado (oxibendazol) e grupo controle. Após o tratamento, os animais foram submetidos à necropsia parasitológica, e os resultados das quantificações de helmintos presentes no trato gastrintestinais indicaram a presença das espécies Ascaris suum, Trichuris suis, Oesophagostomum dentatum e Hyostrongylus rubidus em ordem decrescente de ocorrência. Nos rebanhos suínos brasileiros, os sistemas de produção não tecnificadas podem favorecer a transmissão de helmintos. O tratamento com o oxibendazol obteve eficácia de 100\% para as espécies A. suum e H. rubidus, de 99,65\% para o 0. dentatum
\end{abstract}

Received October 16, 2021. Accepted December 13, 2021.

*Corresponding author: Thaís Rabelo dos Santos-Doni. E-mail: rabelo.vet@hotmail.com

This is an Open Access article distributed under the terms of the Creative Commons Attribution License, which permits unrestricted use distribution, and reproduction in any medium, provided the original work is properly cited. 
e de $99,20 \%$ para o T. suis, reduzindo significativamente $(P<0,01)$ as contagens de helmintos, comprovando que o uso do oxibendazol é eficaz no controle dos principais helmintos de suínos.

Palavras-chave: Anti-helmíntico, oxibendazol, nematódeos, suínos.

Brazil is currently the fourth largest producer and exporter of pork in the world (ABCS, 2020). In recent decades, the worldwide consumption of meat, including pork, has increased markedly. In 2019, per capita pork consumption in Brazil was $15.3 \mathrm{~kg} /$ year (ABPA, 2020). In 2015, the biggest consumers of pork were China, the European Union, the United States, Russia, Vietnam, and Brazil, which collectively accounted for $82 \%$ of the global consumption (ABCS, 2016). However, losses in productivity are recurrent problems that are linked to the presence of parasites and other diseases in the herd, which must be rigorously studied so that producers can develop effective control measures (Lopes et al., 2014). In addition to the economic losses, the significance of helminths in swine is mainly due to the fact that many of the related zoonoses are extremely relevant and are typically neglected (Mundim et al., 2004).

Pig feces are a source of pathogenic organisms, including bacteria, viruses, parasites, and fungi (Bornay-Llinares et al., 2006). In Brazil, the most prevalent helminth species in pigs are nematodes (Lignon et al., 1998): Ascaris suum, Trichuris suis, Hyostrongylus rubidus, Oesophagostomum dentatum, Strongyloides ransomi, and Metastrongylus salmi.

Benzimidazoles have been widely used to prevent and treat parasite infections since the introduction of thiabendazole as an antimicrobial, antiprotozoal, antiviral, and anthelmintic drug (Soni, 2014). Oxibendazole, a well-known benzimidazole that contains sulfide and sulfoxide functional groups, which give it a wide range of activities, is an oral anthelmintic heterocyclic compound used in human and veterinary health care (Park et al., 2019; Papich, 2020).

One of the main methods of controlling parasitic diseases in swine production is the strategic use of anthelmintics. The efficacy of oxibendazole as an anthelmintic in pigs has been demonstrated in a study, conducted in the 1980s, in which it showed 100\% efficacy in preventing intestinal worms (Fonseca \& Grisi, 1989).

There have been few studies of the occurrence of intestinal parasite infection or of the use and efficacy of anthelmintic drugs in pigs in Brazil, and most such studies have not been up to date. On the basis of the above, the aim of the present study was to evaluate the anthelmintic efficacy of oral oxibendazole against gastrointestinal nematodes in naturally infected pigs, as well as to describe the occurrence of helminths in the region surrounding the city of Franca, Brazil.

This study was approved by the Animal Research Ethics Committee of the Research and Development in Veterinary Medicine Sector of the Brazilian organization Bioxen (Reference no. 010/2014). The work follows the guidelines published by the Brazilian College of Animal Experimentation and the International Guiding Principles for Biomedical Research Involving Animals established by the Council for International Organizations of Medical Sciences.

The research was carried out on the Cachoeirinha farm, which is located in the municipality of Rifaina ( $20^{\circ} 04^{\prime} 51^{\prime \prime} \mathrm{S}$; $\left.47^{\circ} 25^{\prime} 15^{\prime \prime} \mathrm{W}\right)$, in the state of São Paulo. The study was conducted in accordance with the standards of the following references: VICH GL7: Efficacy of Anthelmintics: General Requirements (Vercruysse et al., 2001); VICH GL16: Efficacy of Anthelmintics: Specific Recommendations for Porcines (Vercruysse et al., 2002); VICH GL9: Good Clinical Practice (FDA, 2001); World Association for the Advancement of Veterinary Parasitology guidelines for evaluating the efficacy of anthelmintics in swine (Hennessy et al., 2006); and the Brazilian technical regulation of antiparistic agents for veterinary use (Brasil, 1997).

For the selection process, fecal samples were collected from 220 pigs. The animals were from various non-industrial (traditional) farms in the Franca region and were identified by their ear tags. From these 220 samples, we selected 18 hybrid (Sus scrofa domesticus) pigs-9 males and 9 females; 2-5 months in age; and weighing 20-35 kg. All of the animals were acquired from farms with a history of intestinal worm infection and were selected by counting the eggs per gram (EPG > 500) of feces, as described by Gordon \& Whitlock (1939). After the presence of helminths had been confirmed, the animals were purchased commercially and transferred to the experimental farm, where they were housed in $5.1 \mathrm{~m}^{2}$ stalls. Treated and control animals were housed in separate areas, with individual access to food and water, and were exposed to natural conditions of light, humidity, and temperature.

The animals were acclimatized over a period of five days, before treatment, designated day negative 5 (D-5) through day negative $1(D-1)$, period which they received commercial feed ad libitum. Feed consumption was 
monitored to guarantee the ingestion of the indicated dose of the product tested. During that period, the animals were weighed to calculate the dose to be administered to each animal.

The day before the start of treatment, two animals with an EPG count $>500$ were euthanized in order to identify the helminth species and stages of development, as well as to ensure the efficiency of the selection process. After those two animals had been euthanized, animal 12 died, reducing the number of animals in the sample to 15 . The 15 remaining animals were divided into two groups: control $(n=7)$, comprising untreated pigs; and treated $(n=8)$, comprising pigs treated with oxibendazole.

Treatment with oral oxibendazole was carried out for ten consecutive days, designated day 0 (D0) through day 9 (D9). Stratification occurred on D0 and was determined based on sex and mean EPG count in the three days prior to treatment. The animals were listed in descending order by the mean EPG counts on D-3, D-2, and D-1 (group control - mean EPG = 633; group treated - EPG $=638$ ). The first animal of each sex with the highest mean EPG count was randomly allocated in one of the repetitions (1 or 2), the procedure being repeated until all of the animals had been allocated, in order to compose groups that were homogeneous. Five days after the last day of treatment, each animal was euthanized and submitted to necropsy with parasitological examination.

On D0 through D9, the animals in the treated group were fed the same chow used in the acclimatization period, to which the oxibendazole was added at $20 \mathrm{mg}$ of commercial product (Oxyverm ${ }^{\circledR}$ - Oxibendazol 10\%, Farmabase Saúde Animal) per kilogram of body weight per day, administered orally for ten consecutive days ( $2 \mathrm{mg} / \mathrm{kg} / \mathrm{day}$ ). That corresponds to a daily dose of oxibendazole of $2 \mathrm{mg}$ per kilogram of body weight. To ensure total consumption of the product, the animals were given only $80 \%$ of the mean quantity of feed consumed on $\mathrm{D}-3, \mathrm{D}-2$, and $\mathrm{D}-1$. The diet of the animals in the control group was managed in the same way as that of those in the treated group, although it was free of any medication. The animals in both groups had ad libitum access to water.

The animals were humanely euthanized 15 days after the start of treatment. Procedures for organ harvesting, parasite recovery, and worm counting were in accordance with the recommendations of the World Association for the Advancement of Veterinary Parasitology (Hennessy et al., 2006), as well as with other guidelines such as those issued by the U.S. Food and Drug Administration Center for Veterinary Medicine (FDA, 2001; Vercruysse et al., 2001, 2002).

The esophagus, stomach, small intestine, and large intestine were tied with a double ligature and removed, after which the contents were carefully washed and sieved through a Tyler 48 mesh $(0.297 \mathrm{~mm})$ sieve, leaving only the solid contents of each segment, which were placed in appropriate containers with $10 \%$ formalin heated to $80^{\circ} \mathrm{C}$ (Hennessy et al., 2006). The other organs (lungs, heart, liver, pancreas, and kidneys) were also carefully examined, any and all helminths being collected (Vercruysse et al., 2002).

The counts and identification of helminth genera were performed with a stereomicroscope. The species were identified in accordance with the taxonomic criteria described previously (Costa, 2013).

The anthelmintic efficacy of the compound was calculated for arithmetic and geometric means as follows: [control group mean - treated group mean] / control group mean $\times 100$.

The statistical analysis was based on a comparative study between the control group and the treated group in terms of the counts for each parasite species. Prior to analysis, a logarithmic transformation $[\ln (x+1)]$ was applied to the worm count data. The transformed values were analyzed using a general linear mixed model, including fixed (treatment group) effects and random effects. Geometric means and the corresponding 95\% confidence intervals were obtained by using the transformed values. Treatment differences were assessed with the Wilcoxon rank-sum test, at a significance level of 5\% $(P<0.05)$. Statistical calculations were performed with the Stata SE statistical software package, version 16.1 (StataCorp, College Station, TX, USA).

None of the animals employed in this study showed adverse effects during the experiment. The species found in the pigs evaluated were A. suum, T. suis, O. dentatum, and H. rubidus (Table 1).

As a common practice, pig farmers administer anthelmintics mixed with food or water for one to ten consecutive days. The use of benzimidazoles as broad-spectrum anthelmintics in all age groups of pigs is a common practice in different regions of the world (Theodoropoulos et al., 2001; Beloeil et al., 2003).

As can be seen in Table 1, oxibendazole, administered orally for ten consecutive days, showed high (>99.00\%) efficacy against all nematodes found $(P<0.01)$. One of the benefits of effective anthelmintic treatment is that it reduces environmental contamination by removing female parasites, which act as sources of infection for other susceptible hosts. Anthelmintics with ovicidal activity can also minimize environmental contamination. The ovicidal 


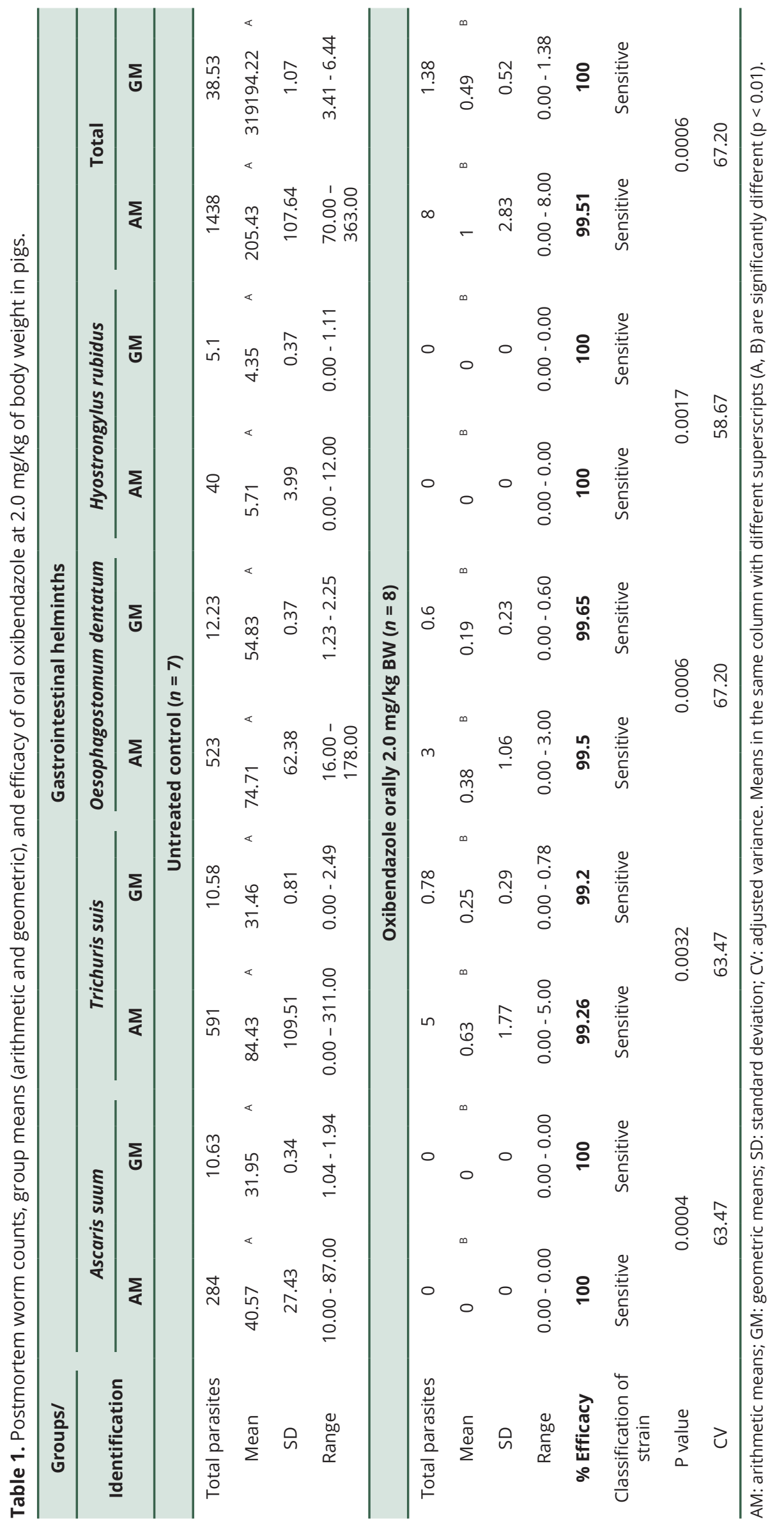


activity of benzimidazole anthelmintics has been demonstrated in a wide variety of nematode species (Zhao et al., 2017).

It is important to highlight the high efficacy of oxibendazole against $O$. dentatum and $T$. suis, which are released in the intestine and migrate to the superficial mucosa of the cecum and colon, which typically makes them resistant to anthelmintic treatments (Alvarez et al., 2013; Jouvin \& Kinet, 2012; Lopes et al., 2014). Similar results were obtained by Alvarez et al. (2013), who studied the anthelmintic activity of oral oxfendazole administered to naturally parasitized piglets in a single dose of $30 \mathrm{mg} / \mathrm{kg}$ of body weight, finding it to be safe and highly (100\%) effective against the adult stages of A. suum, Oesophagostomum spp., T. suis, and Metastrongylus spp.

Dias et al. (2011) evaluated the effectiveness of fenbendazole $4 \%$, at $250 \mathrm{~g}$ per ton of pig feed, for ten days. When A. suum was identified during slaughter, the farms from which the pigs came carried out a new deworming protocol, which consisted of administering the drug to all batches of animals on the farm and repeating the protocol after 20 days. The authors reported that the booster treatments were ineffective.

In Brazilian swine herds, non-industrial production systems can favor the transmission of helminths. Growing knowledge about the survival and infectivity of $A$. suum and $T$. suis eggs on pastureland indicates that they can pose a serious threat to free-range swine production. In addition, it is evident that $A$. suum is zoonotic and the same may be true for T. suis (Roepstorff et al., 2011). Given these new challenges and the economic impact of such infections, more research is needed. In the present study, oxibendazole was found to be highly effective against all of the helminths evaluated, providing a $\geq 99 \%$ reduction in the counts for each species and presenting a statistically significant difference $(P<0.01)$ when compared with the control group.

There have been few studies of the use and efficacy of anthelmintic drugs in pigs in Brazil, and most such studies have not been up to date, therefore the use of oxibendazole can be an alternative to, farmers and veterinarians that must always be aware that parasites are present, furthermore must remain permanently aware of the management system and control practices in order to limit the risk that the number of parasites will increase, which would result in production losses.

Considering the results obtained with the experimental model proposed, we can conclude that the product evaluated provides significant reductions in helminth counts among naturally parasitized swine. Oxibendazole, administered orally for ten consecutive days ( $2 \mathrm{mg} / \mathrm{kg} /$ day), appears to be a viable alternative for the control and treatment of pigs naturally infected with this helminths.

\section{References}

Alvarez L, Saumell C, Fusé L, Moreno L, Ceballos L, Domingue G, et al. Efficacy of a single high oxfendazole dose against gastrointestinal nematodes in naturally infected pigs. Vet Parasitol 2013; 194(1): 70-74. http://dx.doi.org/10.1016/j. vetpar.2013.01.003. PMid:23357598.

Associação Brasileira de Criadores de Suínos - ABCS. Dados de mercado da suinocultura [online]. Brasília: ABCS; 2020 [cited 2021 Aug 10]. Available from: http://abcs.org.br/dados-do-setor/

Associação Brasileira de Proteína Animal - ABPA. Relatório anual [online]. São Paulo: ABPA; 2020 [cited 2021 Aug 10]. Available from: https://abpa-br.org/relatorios/

Associação Brasileira dos Criadores de Suínos - ABCS. Serviço Brasileiro de Apoio às Micro e Pequenas Empresas - SEBRAE. Mapping of brazilian pork chain [online]. Brasília: ABCS/SEBRAE; 2016 [cited 2021 Aug 10]. p. 376. Available from: http://abcs.org. $\mathrm{br} / \mathrm{material/mapeamento-da-suinocultura-brasileira/}$

Beloeil P, Chauvin C, Fablet C, Jolly J, Eveno E, Madec F, et al. Helminth control practices and infections in growing pigs in France. Livest Prod Sci 2003; 81(1): 99-104. http://dx.doi.org/10.1016/S0301-6226(02)00192-6.

Bornay-Llinares FJ, Navarro-I-Martínez L, García-Orenes F, Araez H, Pérez-Murcia MD, Moral R. Detection of intestinal parasites in pig slurry: a preliminary study from five farms in Spain. Livest Sci 2006; 102(3): 237-242. http://dx.doi.org/10.1016/j.livsci.2006.03.023.

Brasil. Ministério da Agricultura, Pecuária e Abastecimento - MAPA. Secretaria de Defesa Agropecuária -SDA. Portaria N 48, de 12 de maio de 1997. Regulamento técnico para licenciamento e/ou renovação de licença de produtos antiparasitarios de uso veterinário. Diário Oficial da República Federativa do Brasil [online]. Brasília, 1997 [cited 2021 Aug 15]. Available from: https:// www.gov.br/agricultura/pt-br/assuntos/insumos-agropecuarios/insumos-pecuarios/produtos-veterinarios/legislacao-1/portaria/ portaria-sda-mapa-no-48-de-12-05-1997.pdf/view

Costa AJ. Diagnóstico parasitológico em helmintologia. Jaboticabal: FUNEP; 2013. 
Dias AS, Tanure AM, Manhães HGVC. Ocorrência de Ascaris suum em suínos abatidos na Zona da Mata, Minas Gerais. Braz J Vet Res Anim Sci 2011; 48(2): 101-106. http://dx.doi.org/10.11606/S1413-95962011000200001.

Fonseca AH, Grisi L. Uso contínuo do anti-helmíntico oxibendazole na ração de suínos do desmame ao abate. Pesq Agropec Bras 1989; 24(1): 69-73.

Food and Drug Administration - FDA. Center for Veterinary Medicine - CVM. Guidance for Industry\# 85; Good Clinical PracticeVICH GL9 [online]. Rockville, MD: FDA; 2001. Available from: https://vichsec.org/en/guidelines/pharmaceuticals/pharma-efficacy/ good-clinical-practice.html

Gordon HM, Whitlock HV. A new technique for counting nematode eggs in sheep faeces. J Counc Sci Ind Res 1939; 12 (1): 50-52.

Hennessy DR, Bauer C, Boray JC, Conder GA, Daugschies A, Johansen MV, et al. World association for the advancement of veterinary parasitology (WAAVP): second edition of guidelines for evaluating the efficacy of anthelmintics in swine. Vet Parasitol 2006; 141(1-2): 138-149. http://dx.doi.org/10.1016/j.vetpar.2006.04.038.

Jouvin MH, Kinet JP. Trichuris suis ova: testing a helminth-based therapy as an extension of the hygiene hypothesis. J Allergy Clin Immunol 2012; 130(1): 3-10, quiz 11-12. http://dx.doi.org/10.1016/j.jaci.2012.05.028. PMid:22742834.

Lignon GB, de Paiva DP, Sobestiansky J, Souza AP. Controle de endoparasitas. In: Sobestiansky J, Wentz I, Silveira PRS, Sesti LAC, editors. Suinocultura intensiva: produção, manejo e saúde do rebanho. Brasília: EMBRAPA; 1998. p. 275-289.

Lopes WDZ, Teixeira WFP, Felippelli G, Cruz BC, Buzulini C, Maciel WG, et al. Anthelmintic efficacy of ivermectin and abamectin, administered orally for seven consecutive days $(100 \mu \mathrm{g} / \mathrm{kg} /$ day), against nematodes in naturally infected pigs. Res Vet Sci 2014 ; 97(3): 546-549. http://dx.doi.org/10.1016/j.rvsc.2014.09.007. PMid:25278142.

Mundim MJS, Mundim AV, Santos ALQ, Cabral DD, Faria ESM, Moraes FM. Helmintos e protozoários em fezes de javalis (Sus scrofa scrofa) criados em cativeiro. Arq Bras Med Vet Zootec 2004; 56(6): 792-795. http://dx.doi.org/10.1590/S0102-09352004000600015.

Papich MG. Oxibendazole. In: Papich MG, editor. Papich handbook of veterinary drugs (5th ed.). St. Louis, MO: Saunders Elsevier; 2020. p. 681-683. https://doi.org/10.1016/C2018-0-04649-6.

Park H, Lim W, You S, Song G. Oxibendazole induces apoptotic cell death in proliferating porcine trophectoderm and uterine luminal epithelial cells via mitochondria-mediated calcium disruption and breakdown of mitochondrial membrane potential. Comp Biochem Physiol C Toxicol Pharmacol 2019; 220: 9-19. http://dx.doi.org/10.1016/j.cbpc.2019.02.014. PMid:30822534.

Roepstorff A, Mejer H, Nejsum P, Thamsborg SM. Helminth parasites in pigs: new challenges in pig production and current research highlights. Vet Parasitol 2011; 180(1-2): 72-81. http://dx.doi.org/10.1016/j.vetpar.2011.05.029. PMid:21684689.

Soni B. A short review on potential activities of benzimidazole derivatives. PharmaTutor 2014; 2(8): 110-118.

Theodoropoulos G, Theodoropoulou E, Melissaropoulou G. Worm control practices of pig farmers in Greece. Vet Parasito/ 2001; 97(4): 285-293. http://dx.doi.org/10.1016/S0304-4017(01)00414-9. PMid:11390082.

Vercruysse J, Holdsworth P, Letonja T, Barth D, Conder G, Hamamoto K, et al. International harmonisation of anthelmintic efficacy guidelines. Vet Parasitol 2001; 96(3): 171-193. http://dx.doi.org/10.1016/S0304-4017(00)00443-X. PMid:11240092.

Vercruysse J, Holdsworth P, Letonja T, Conder G, Hamamoto K, Okano K, et al. International harmonisation of anthelmintic efficacy guidelines (Part 2). Vet Parasito/ 2002; 103(4): 277-297. http://dx.doi.org/10.1016/S0304-4017(01)00615-X. PMid:11777607.

Zhao J, Han Q, Liao C, Wang J, Wu L, Liu Q, et al. Effects of In Vivo and in vitro treatment of Ascaris suum eggs with anthelmintic agents on embryonation and infectivity for mice. J Parasito/ 2017; 103(5): 598-601. http://dx.doi.org/10.1645/17-21. PMid:28590167. 